\title{
Isolation, Identification, Biochemical and Antibiotic Sensitivity Characterization of Rhizobium Strains from Vigna mungo (L) Hepper, Cicer arietinum $\mathrm{L}$ and Vigna radiata $(\mathrm{L}) \mathrm{R}$ Wilczek in Muzaffarnagar, Uttar Pradesh, India
}

\author{
Ankur Tyagi ${ }^{1 *}$, Vijay Kumar ${ }^{2}$, Purushottam ${ }^{1}$ and Akash Tomar ${ }^{3}$ \\ ${ }^{1}$ Department of Pathology and Microbiology, ${ }^{3}$ Department of Recombination Technique, College \\ of Biotechnology, SVP University of Agriculture and Technology, \\ Modipuram, Meerut (U.P.), India \\ ${ }^{2}$ Department of Plant Pathology, Dr Y S Parmar University of Horticulture and Forestry, \\ Nauni, Solan (HP)-173230, India \\ *Corresponding author
}

\begin{tabular}{|c|c|}
\hline & B S T R A C T \\
\hline & \multirow{6}{*}{$\begin{array}{l}\text { In present investigation uard (Vigna mungo (L) Hepper), chickpea (Cicer arietinum L) and } \\
\text { moong (Vigna radiata (L) R Wilczek) were studied for isolation, identification, } \\
\text { biochemical and antibiotic activities characterization of Rhizobium strains. A total of } 37 \\
\text { samples were screened out of which } 27 \text { samples of Cicer arietinum, } 5 \text { samples of Vigna } \\
\text { mungo and } 5 \text { samples of Vigna radiata were collected from different fields of surrounding } \\
\text { area of Muzaffarnagar, Uttar Pradesh. On the basis of white mucoid growth on YEMA } \\
\text { medium only } 3 \text { samples from Vigna mungo, } 18 \text { (Cicer arietinum) and none of sample } \\
\text { Vigna radiata from were found positive for the presence of Rhizobium. In Gram staining } \\
\text { reaction all the } 21 \text { (18 from chickpea and } 3 \text { from uard) isolates were found Gram-negative } \\
\text { and rod shaped. Biochemical characterization of Rhizobium strains showed that all the } 21 \\
\text { isolates have negative reaction with Citrate utilization test, Starch utilization test was } \\
\text { positive with all isolates except for U1, C3, C13 and C24, Glucose peptone agar test was } \\
\text { positive with all isolates except for C } 18 \text {, negative results were found with Gelatin test for } \\
\text { all isolates and Catalase test was found positive for all isolates. All the isolates were found } \\
\text { sensitive to Ciprofloxacin (Cf) except C12 which was partially resistant, Ofloxacin (Of) } \\
\text { except C2 which was partially resistant. Norfloxacin (Nx) was susceptible to } 11 \text { isolates, } \\
\text { resistant to } 7 \text { isolates and partial resistant to } 3 \text { isolates. Levofloxacin (Le) and Gatifloxacin } \\
\text { (Gf) were susceptible to all isolate but Levofloxacin (Le) was partial resistant to C3, C8 } \\
\text { and C14. All the isolates, on the other hand, showed resistance to antibiotics Aztreonam } \\
\text { (Ao) and Co-trimoxazole (Co) were showed resistant while Nitrofurantoin (Nf) showed } \\
\text { partial resistance to isolates with few exception. }\end{array}$} \\
\hline Keywords & \\
\hline $\begin{array}{l}\text { Isolation, } \\
\text { Biochemical } \\
\text { characterization, } \\
\text { Antibiotic activity, } \\
\text { Rhizobium. }\end{array}$ & \\
\hline Artic & \\
\hline & \\
\hline & \\
\hline
\end{tabular}

\section{Introduction}

Nitrogen is an essential nutrient for plant growth and development. Nitrogen is an important element for the synthesis of amino acids which are used by the plant to form protein. Plants primarily take nitrogen in the ionic form of either ammonium or nitrate. Intensive farming practices that accomplish high yields need chemical fertilizers, which 
are costly and also create environmental problems (Rigby and Caceres, 2001). The extensive use of chemical fertilizers in agriculture is currently under debate due to environmental concern and fear for consumer's health. Consequently, there has recently been a growing level of interest in environment friendly sustainable agricultural practices and organic farming systems (Lee and Song, 2007). Leguminous plants are also able to utilize nitrogen derived from the symbiotic relationship they form with root nodule bacteria. This phenomenon is extremely important and the value of this "free" fertilizer $\mathrm{N}_{2}$ can be placed in global perspective if one considers that an estimated 50 million tons of nitrogen is manufactured industrially each year against an estimated 90 million tons fixed by plant processes (Cleyet et al., 1990). The genus Rhizobium was given by Frank in 1890, based on its characters to form nodules on roots of legume plants (Graham and Parker, 1964). Root-nodule bacteria are separated into two genera Rhizobium which are fast growing bacteria and Bradyrhizobium which are slow growers (Jordan, 1984). Rhizobia are soil bacteria that fix $\mathrm{N}_{2}$ (diazotroph) after becoming established inside root nodules of legumes (Fabaceae). There are several different genera of Rhizobia, all of them belong to the Rhizobiales, a probably-monophyletic group of protobacteria and they are soil bacteria characterized by their unique ability to infect root hairs of legumes and induce effective $\mathrm{N}_{2-}$ fixing nodules to form on the roots. Unlike many other soil microorganisms, Rhizobia produce no spores and they are rod shaped, aerobic and motile (Chaintreuil et al., 2000). Inoculation plants and spoil with Rhizobium can improved soil fertility and reduce the production cost of next crop through reduced input in the form of nitrogen fertilizers and which also minimize hazard effects of fertilizers on human, soil and environmental health (Mia and Shamsudin, 2010).
There is one more beneficial aspect of exploitation of Rhizobium in agricultural practice that the excessive use of chemicals to control plant diseases lead to groundwater contamination, development of resistant races of pathogen, human health hazardous and environmental detrimental (Akhar et al., 2009) and this shift the attention towards the plant growth-promoting Rhizobacteria (PGPR) which in recent years proved to be an alternative to chemicals by controlling the plant diseases effectively especially the soil and seed-borne pathogens (Beneduz et al., 2012, Gupta et al., 2015).

\section{Materials and Methods}

The experiments were carried out at the Department of Pathology and Microbiology, College of Biotechnology, SVP University of Agriculture and Technology, Modipuram, Meerut (U.P.).

\section{Collection of samples}

Plant samples were collected from the different locations of Muzaffarnagar such as Charthawal, Thanabhawan, Khatauli, Bhagra, Janshat, Budhana, and Purkaji. A total of 5 samples of urad, 27 samples of chickpea and 5 samples of moong were collected and taken from the field to the laboratory for the isolation of Rhizobium strains. The detail of the plant samples collection location was given in Table 1.

\section{Isolation}

The uproot plant samples are brought into the laboratory, tagged properly and named as U1U5 for urad, C1-C27 for chickpea, and M1M5 for moong. These samples were washed carefully so that nodules are not getting separated from the plant roots. Nodules from the respective leguminous crop plants are picked with sterile forceps. These nodules are 
then surface sterilized (with the help of $1 \%$ sodium hypochloride) followed by washing with alcohol and distilled water. Then the nodules are placed onto a clean glass slide and smoothly crushed with another slide, so to obtain a juicy liquid containing the bacteria. This liquid substance is used as the inoculum for the isolation of Rhizobium.

The isolation is done on selective medium for Rhizobium i.e. YEMA (Yeast Extract Mannitol Agar) media through streak plate method. The streaked plates were incubated at $35^{\circ} \mathrm{C}$ for 24 hours and are observed for the appearance of growth. White mucoid colonies appear on streaked Petri plates than it proved the presence of Rhizobium. These white and mucoid colonies are picked up separately and inoculated on nutrient agar slants in two replicates and incubated at $35^{\circ} \mathrm{C}$ for $24 \mathrm{~h}$. After incubation, if proper growth is there, slants were stored at $4^{0} \mathrm{C}$ in refrigerator for further characterization.

\section{Gram staining}

Bacterial smear of different strains was prepared separately and fixed in flame. Smears were fixed by passing over a Bunsen burner flame and then stained with ammonium oxalate crystal violet for one minute. Then, it was washed with tap water and immersed in Gram's iodine for one minute. Again washed with tap water and blot dried smear was flooded with $95 \%$ ethyl alcohol (decolorize) for $30 \mathrm{sec}$.

It was again washed with water and blot dried carefully. Then it was counter stained with safranin, again washed with tap water and finally dried and examined under oil immersion objective on the microscope. Gram-negative bacteria retain the pink/red colour while Gram-positive bacteria retain the crystal-violet.

\section{Biochemical characterization of Rhizobium}

Biochemical characterization of different isolates was done for the identification of Rhizobium on the basis of different biochemical tests viz., Citrate utilization test, Triple sugar iron test, Glucose peptone agar utilization test, Gelatin liquefaction test, Starch utilization test and Catalase test.

\section{Citrate utilization test}

In this medium citrate is the only carbon source available to the bacteria; however, the Rhizobium cannot grow on the citrate and therefore, no change in colour occurs. To inoculate the slant, a loopfull of culture of Rhizobium was used; the slant was inoculated following stab and streak method and finally observed after incubation period of $24 \mathrm{~h}$ at $37^{0} \mathrm{C}$.

\section{Triple sugar iron agar test}

It was performed to determine the capability of isolates to use various carbohydrate sources (e.g. sucrose, glucose, lactose) as media for growth (Kligler, 1918; Hajnaa, 1945).

\section{Starch utilization test}

The test was performed to determine the capability of microorganism to use starch as carbon source (De Oliveria et al., 2007). Starch agar media were inoculated with Rhizobium, incubated and analyzed. In the presence of starch, the production of extra cellular enzymes occurs indicating the potential of the organism to use starch as carbon source. Iodine test was used to determine capability of microorganisms to use starch. Drops of iodine solution were spread on $24 \mathrm{~h}$ old cultures grown in Petri-plates. Formation of blue color indicated nonutilization of starch and vice versa. 


\section{Glucose peptone agar (GPA) test}

GPA assay was performed to determine the capability of the microorganism to utilize glucose as the sole carbon source for its growth (Singh et al., 2008). GPA medium was inoculated with Rhizobium culture, incubated and growth was observed.

\section{Gelatin test}

This test was performed to determine capability of microorganisms to produce gelatinase enzyme and use gelatin as media source. Degradation of gelatin indicates the presence of gelatinase enzyme. The actively grown cultures were inoculated in nutrient gelatin medium and grown for $48 \mathrm{~h}$. On subjecting the growing culture to low temperature treatment at $4^{0} \mathrm{C}$ for $30 \mathrm{~min}$, the cultures which produce gelatinase remain liquefied while others due to presence of gelatin become solid (Aneja, 2003).

\section{Catalase test}

This test was performed to study the presence of catalase enzyme in bacterial colonies. Rhizobium colonies ( $24 \mathrm{~h}$ old) were taken on glass slides and one drop of $\mathrm{H} 2 \mathrm{O} 2(30 \%)$ was added. Appearance of gas bubble indicated the presence of catalase enzyme (MacFaddin, 1980).

\section{Antibiotic sensitivity test}

Antimicrobial discs used were of Ciprofloxacin (Cf), Ofloxacin (Of), Norfloxacin (Nx), Levofloxacin (Le), Aztreonam (Ao), Gatifloxacin (Gf), Nitrofurantoin (Nf), Co-trimoxazole (Co). All the isolates were inoculated in YEM broth separately and incubated at $37^{\circ} \mathrm{C}$ for $12 \mathrm{~h}$. The culture broth of each isolate was spread as thin layer separately on the nutrient agar medium (NAM) using a sterile cotton swab. Antimicrobial discs were placed on the inoculated plates of different isolates at a distance of approximately $2.5 \mathrm{~cm}$ and then incubated overnight at $37^{\circ} \mathrm{C}$. The sensitivity or the resistance of Rhizobium isolates to antibiotics was determined by observing the absence or presence of growth around the discs. Those isolates which show growth around a particular antibiotic are resistant to that corresponding antibiotic, whereas, the isolates whose growth is inhibited by a particular antibiotic seem to be sensitive to that particular antibiotic (Persuna, 2014)

\section{Results and Discussion}

A total of 37 root nodule samples collected from different leguminous crops (5 samples of urad, 27 samples of chickpea and 5 samples of moong) of Muzaffarnagar region were used for the isolation and identification of Rhizobium strains in the laboratory (Figure 1,2,3 and 4). The data in Table 2 revealed that among 37 samples tested, 21 (18 of chickpea, 3 of uard and none from moong) samples were found positive for the presence of Rhizobium on the basis of white mucoid growth on YEMA medium when incubated for $24 \mathrm{~h}$ at $35^{\circ} \mathrm{C}$ (Figure 5 and 6). All the 21 samples that showed the presence of Rhizobium when subjected to Gram staining and all the isolates (18 from chickpea and 3 from uard) were found Gram-negative as the cells appeared pink after Gram staining. After Gram staining, all the isolates are preserved on nutrient agar medium slants for further characterization.

\section{Biochemical characterization}

Characterization of different isolates was done on the basis of different biochemical tests viz. Citrate utilization test, Triple sugar iron test, Glucose peptone agar utilization test, Gelatisn liquefaction test, Starch utilization test and Catalase test). The results of different biochemical tests are represented in Table 3 and Figures 7 and 8. 
Table.1 Collection details of plant samples

\begin{tabular}{|l|l|c|l|}
\hline S.No. & Location of sample & No. of samples & Crops \\
\hline 1. & Charthawal & 10 & Chickpea (C) \\
2. & Thanabhawan & 10 & Chickpea (C) \\
3. & Khatauli & 5 & Chickpea (C) \\
4. & Bhagra & 2 & Chickpea (C) \\
5. & Janshat & 3 & Urad (U) \\
6. & Budhana & 2 & Urad (U) \\
7. & Purkaji & 5 & Moong (M) \\
\hline
\end{tabular}

Table.2 Different samples showing the presence or absence of white mucoid colonies on YEMA after $24 \mathrm{~h}$ incubation

\begin{tabular}{|c|c|c|c|c|}
\hline S.No. & Crop & Sample No. & Location & Creamy/white mucoid colonies \\
\hline \multirow{28}{*}{1.} & \multirow{27}{*}{ Chickpea } & $\mathrm{C}_{1}$ & Charthawal & - \\
\hline & & $\mathrm{C}_{2}$ & " & + \\
\hline & & $\mathrm{C}_{3}$ & $"$ & + \\
\hline & & $\mathrm{C}_{4}$ & $"$ & + \\
\hline & & $\mathrm{C}_{5}$ & $"$ & - \\
\hline & & $\mathrm{C}_{6}$ & $"$ & - \\
\hline & & $\mathrm{C}_{7}$ & $"$ & - \\
\hline & & $\mathrm{C}_{8}$ & $"$ & + \\
\hline & & $\mathrm{C}_{9}$ & $"$ & + \\
\hline & & $\mathrm{C}_{10}$ & $"$ & + \\
\hline & & $\mathrm{C}_{11}$ & Thanabhawan & - \\
\hline & & $\mathrm{C}_{12}$ & " & + \\
\hline & & $\mathrm{C}_{13}$ & $"$ & + \\
\hline & & $\mathrm{C}_{14}$ & $"$ & + \\
\hline & & $\mathrm{C}_{15}$ & $"$ & + \\
\hline & & $\mathrm{C}_{16}$ & $"$ & - \\
\hline & & $\mathrm{C}_{17}$ & $"$ & - \\
\hline & & $\mathrm{C}_{18}$ & " & + \\
\hline & & $\mathrm{C}_{19}$ & $"$ & + \\
\hline & & $\mathrm{C}_{20}$ & $"$ & + \\
\hline & & $\mathrm{C}_{21}$ & Khatauli & + \\
\hline & & $\mathrm{C}_{22}$ & " & - \\
\hline & & $\mathrm{C}_{23}$ & " & + \\
\hline & & $\mathrm{C}_{24}$ & $"$ & + \\
\hline & & $\mathrm{C}_{25}$ & $"$ & + \\
\hline & & $\mathrm{C}_{26}$ & Bhagra & + \\
\hline & & $\mathrm{C}_{27}$ & $"$ & - \\
\hline & \multirow{6}{*}{ Urad } & $\mathrm{U}_{1}$ & Janshat & + \\
\hline \multirow{5}{*}{2.} & & $\mathrm{U}_{2}$ & $"$ & - \\
\hline & & $\mathrm{U}_{3}$ & $"$ & + \\
\hline & & $\mathrm{U}_{4}$ & Budhana & + \\
\hline & & $\mathrm{U}_{5}$ & $"$ & - \\
\hline & & $\mathrm{M}_{1}$ & Purkaji & - \\
\hline \multirow{4}{*}{3.} & Moono & $\mathrm{M}_{2}$ & $"$ & - \\
\hline & Nioong & $\mathrm{M}_{3}$ & 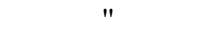 & - \\
\hline & & $\mathrm{M}_{4}$ & 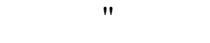 & - \\
\hline & & $\mathrm{M}_{5}$ & 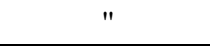 & - \\
\hline
\end{tabular}

*+: Positive result, -: no result (Negative results) 
Table.3 Biochemical characterization of Rhizobium isolates

\begin{tabular}{|c|c|c|c|c|c|c|}
\hline $\begin{array}{c}\text { S. } \\
\text { No. }\end{array}$ & $\begin{array}{c}\text { Samples } \\
\text { No. }\end{array}$ & $\begin{array}{c}\text { Citrate } \\
\text { utilization test }\end{array}$ & $\begin{array}{c}\text { Starch utilization } \\
\text { test }\end{array}$ & $\begin{array}{c}\text { Glucose peptone } \\
\text { agar test }\end{array}$ & Gelatin test & $\begin{array}{c}\text { Catalase } \\
\text { test }\end{array}$ \\
\hline 1. & $\mathrm{U}_{1}$ & - & - & + & - & + \\
\hline 2. & $\mathrm{U}_{3}$ & - & + & + & - & + \\
\hline 3. & $\mathrm{U}_{4}$ & - & + & + & - & + \\
\hline 4. & $\mathrm{C}_{2}$ & - & + & + & - & + \\
\hline 5. & $\mathrm{C}_{3}$ & - & - & + & - & + \\
\hline 6. & $\mathrm{C}_{4}$ & - & + & + & - & + \\
\hline 7. & $\mathrm{C}_{8}$ & - & + & + & - & + \\
\hline 8. & $\mathrm{C}_{9}$ & - & + & + & - & + \\
\hline 9. & $\mathrm{C}_{10}$ & - & + & + & - & + \\
\hline 10. & $\mathrm{C}_{12}$ & - & + & + & - & + \\
\hline 11. & $\mathrm{C}_{13}$ & - & + & + & - & + \\
\hline 12. & $\mathrm{C}_{14}$ & - & + & - & - & + \\
\hline 13. & $\mathrm{C}_{15}$ & - & + & + & - & + \\
\hline 14. & $\mathrm{C}_{18}$ & - & + & + & - & + \\
\hline 15. & $\mathrm{C}_{19}$ & - & + & + & - & + \\
\hline 16. & $\mathrm{C}_{20}$ & - & + & + & - & + \\
\hline 17. & $\mathrm{C}_{21}$ & - & - & + & + & + \\
\hline 18. & $\mathrm{C}_{23}$ & - & + & + & - & + \\
\hline 19. & $\mathrm{C}_{24}$ & - & + & + & - & + \\
\hline 20. & $\mathrm{C}_{25}$ & - & - & + & + & + \\
\hline 21. & $\mathrm{C}_{26}$ & - & + & + & + & + \\
\hline
\end{tabular}

*+: Positive result, -: no result (Negative results)

Table.4 Antibiotic sensitivity of Rhizobium isolates from leguminous root nodule samples

\begin{tabular}{|c|c|c|c|c|c|c|c|c|}
\hline \multirow{2}{*}{ Sample/isolate } & \multicolumn{8}{|c|}{ Reaction } \\
\hline & Cf & Of & $\mathbf{N x}$ & Le & Ao & Gf & $\mathbf{N f}$ & Co \\
\hline $\mathrm{U}_{1}$ & $\mathrm{~S}$ & $\mathrm{~S}$ & $\mathrm{R}$ & $\mathrm{S}$ & $\mathrm{R}$ & $\mathrm{R}$ & R" & $\mathrm{R}$ \\
\hline $\mathrm{U}_{3}$ & $\mathrm{~S}$ & $\mathrm{~S}$ & $\mathrm{R}$ & $\mathrm{S}$ & $\mathrm{R}$ & $\mathrm{S}$ & $S$ & $\mathrm{~S}$ \\
\hline $\mathrm{U}_{4}$ & $\mathrm{~S}$ & $S$ & $\mathrm{~S}$ & $\mathrm{~S}$ & $\mathrm{R}$ & $\mathrm{S}$ & $\mathrm{S}$ & $\mathrm{R}$ \\
\hline $\mathrm{C}_{2}$ & $\mathrm{~S}$ & R" & R" & R" & $\mathrm{R}$ & $\mathrm{S}$ & $\mathrm{R}^{\prime \prime}$ & $\mathrm{R}$ \\
\hline $\mathrm{C}_{3}$ & $\mathrm{~S}$ & $\mathrm{~S}$ & $\mathrm{~S}$ & $\mathrm{~S}$ & $\mathrm{R}$ & $\mathrm{S}$ & R" & $\mathrm{R}$ \\
\hline $\mathrm{C}_{4}$ & $\mathrm{~S}$ & $\mathrm{~S}$ & $\mathrm{R}$ & $\mathrm{S}$ & $\mathrm{R}$ & $\mathrm{S}$ & $\mathrm{R}$ & $\mathrm{R}$ \\
\hline $\mathrm{C}_{8}$ & $\mathrm{~S}$ & $\mathrm{~S}$ & $\mathrm{~S}$ & R" & $\mathrm{R}$ & $\mathrm{S}$ & R" & $\mathrm{S}$ \\
\hline $\mathrm{C}_{9}$ & $\mathrm{~S}$ & $\mathrm{~S}$ & R" & $\mathrm{S}$ & $\mathrm{R}$ & $\mathrm{S}$ & $\mathrm{S}$ & $\mathrm{R}$ \\
\hline $\mathrm{C}_{10}$ & $\mathrm{~S}$ & $\mathrm{~S}$ & $\mathrm{~S}$ & $\mathrm{~S}$ & R" & $\mathrm{S}$ & $\mathrm{S}$ & $\mathrm{R}$ \\
\hline $\mathrm{C}_{12}$ & R" & $\mathrm{S}$ & $\mathrm{S}$ & $\mathrm{S}$ & $\mathrm{R}$ & $\mathrm{S}$ & $S$ & R" \\
\hline $\mathrm{C}_{13}$ & $\mathrm{~S}$ & $\mathrm{~S}$ & $\mathrm{R}$ & $\mathrm{S}$ & $\mathrm{R}$ & $\mathrm{S}$ & R" & R" \\
\hline $\mathrm{C}_{14}$ & $\mathrm{~S}$ & $S$ & $\mathrm{~S}$ & R" & $\mathrm{R}$ & $\mathrm{S}$ & $\mathrm{R}^{\prime \prime}$ & $\mathrm{R}$ \\
\hline $\mathrm{C}_{15}$ & $\mathrm{~S}$ & $\mathrm{~S}$ & $\mathrm{R}$ & $\mathrm{S}$ & $\mathrm{R}$ & $\mathrm{S}$ & $\mathrm{R}$ & $\mathrm{R}$ \\
\hline $\mathrm{C}_{18}$ & $\mathrm{~S}$ & $\mathrm{~S}$ & R" & $\mathrm{S}$ & $\mathrm{R}$ & $\mathrm{S}$ & $\mathrm{S}$ & $\mathrm{R}$ \\
\hline $\mathrm{C}_{19}$ & $\mathrm{~S}$ & $\mathrm{~S}$ & $\mathrm{~S}$ & $\mathrm{~S}$ & $\mathrm{R}$ & $\mathrm{S}$ & R" & $\mathrm{R}$ \\
\hline $\mathrm{C}_{20}$ & $\mathrm{~S}$ & $\mathrm{~S}$ & $\mathrm{R}$ & $\mathrm{S}$ & R" & $\mathrm{S}$ & $\mathrm{S}$ & $\mathrm{S}$ \\
\hline $\mathrm{C}_{21}$ & $\mathrm{~S}$ & $\mathrm{~S}$ & $\mathrm{~S}$ & $\mathrm{~S}$ & $\mathrm{R}$ & $\mathrm{S}$ & $\mathrm{S}$ & $\mathrm{S}$ \\
\hline $\mathrm{C}_{23}$ & $\mathrm{~S}$ & $\mathrm{~S}$ & $\mathrm{R}$ & $\mathrm{S}$ & $\mathrm{R}$ & $\mathrm{S}$ & R" & $\mathrm{R}$ \\
\hline $\mathrm{C}_{24}$ & $\mathrm{~S}$ & $\mathrm{~S}$ & $\mathrm{~S}$ & $\mathrm{~S}$ & $\mathrm{R}$ & $\mathrm{S}$ & $\mathrm{R}^{\prime \prime}$ & R” \\
\hline $\mathrm{C}_{25}$ & $\mathrm{~S}$ & $\mathrm{~S}$ & $\mathrm{~S}$ & $\mathrm{~S}$ & $\mathrm{R}$ & $\mathrm{S}$ & $\mathrm{S}$ & $\mathrm{R}$ \\
\hline $\mathrm{C}_{26}$ & $\mathrm{~S}$ & $\mathrm{~S}$ & $\mathrm{~S}$ & $\mathrm{~S}$ & $\mathrm{R}$ & $\mathrm{S}$ & R" & $\mathrm{R}$ \\
\hline
\end{tabular}

*S:- Sensitive, R:- Resistance, R":- Partial resistance 
Fig.1 Field of Urad (Vigna mungo)

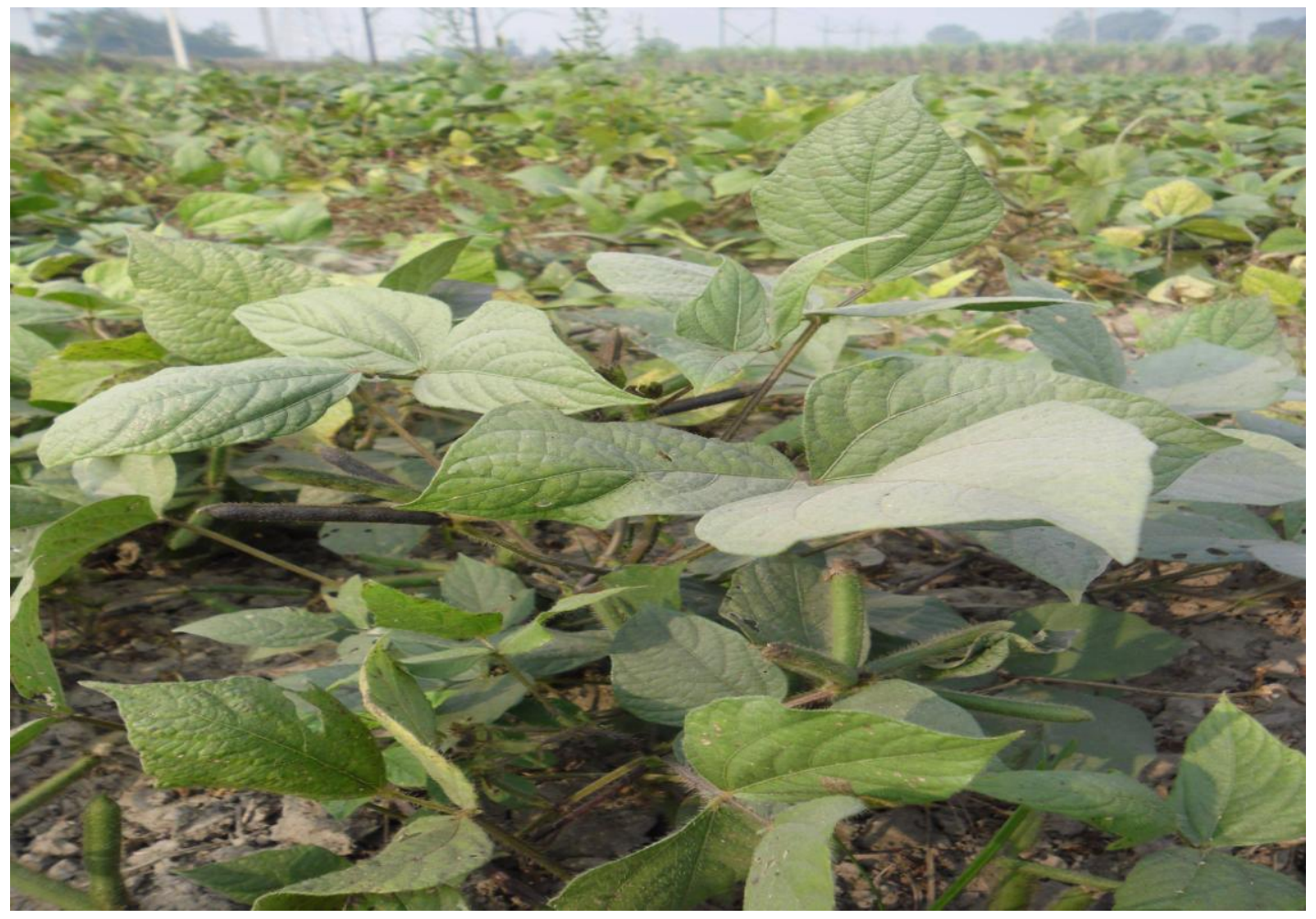

Fig.2 Collection of Urad sample from the field

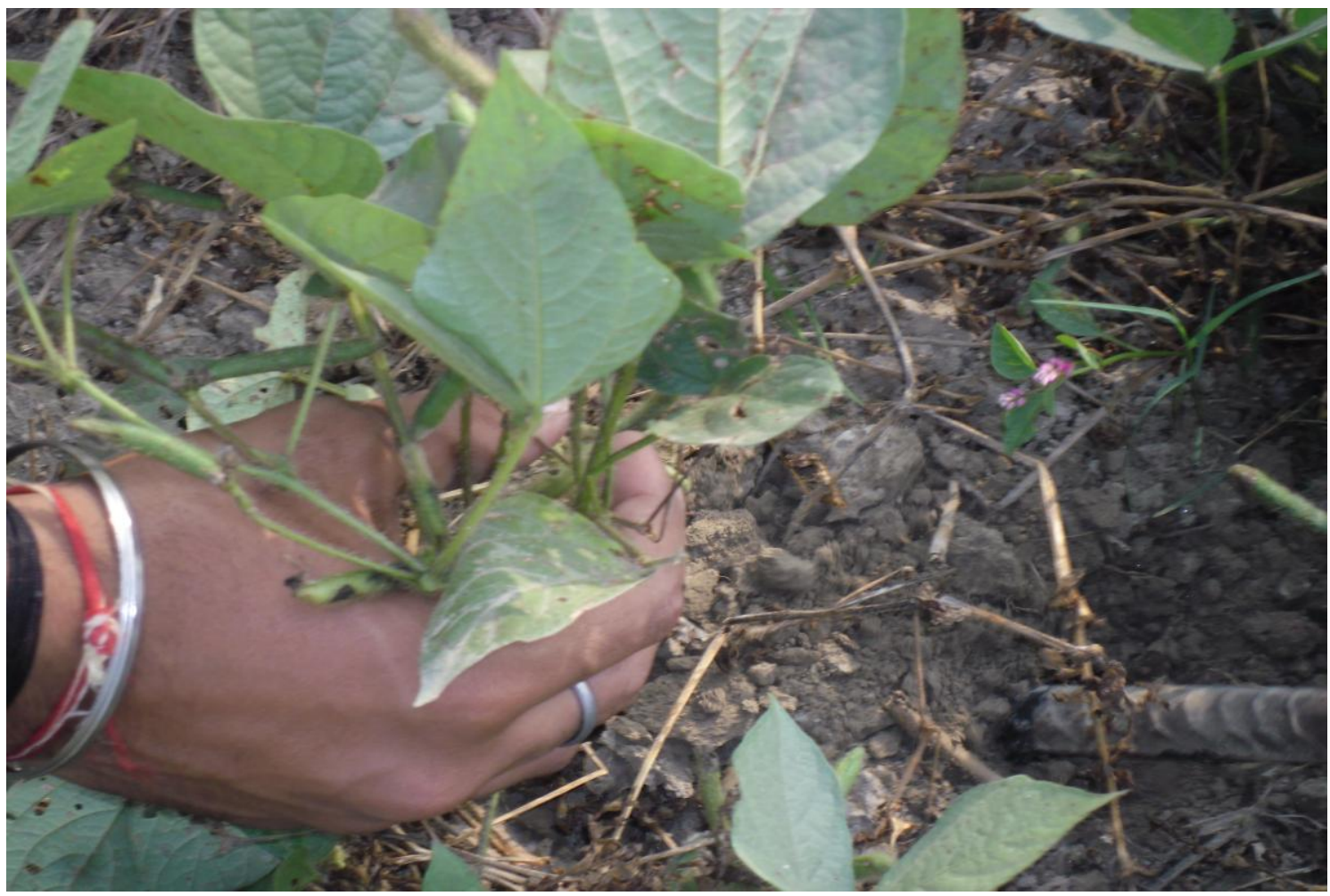


Fig.3 Root nodules of Urad plant (Vigna mungo)

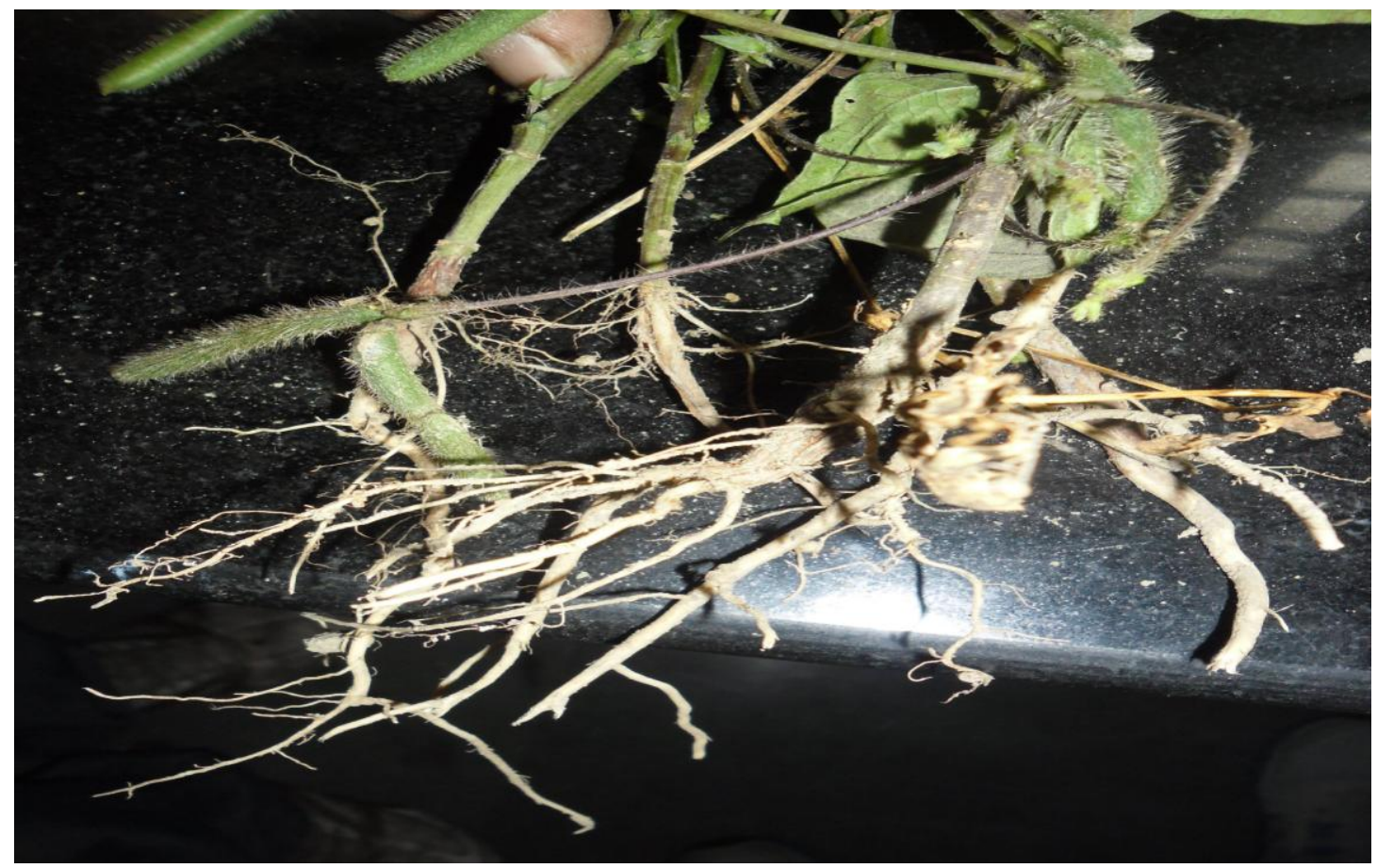

Fig.4 Root nodules of chickpea plant (Cicer arietinum)

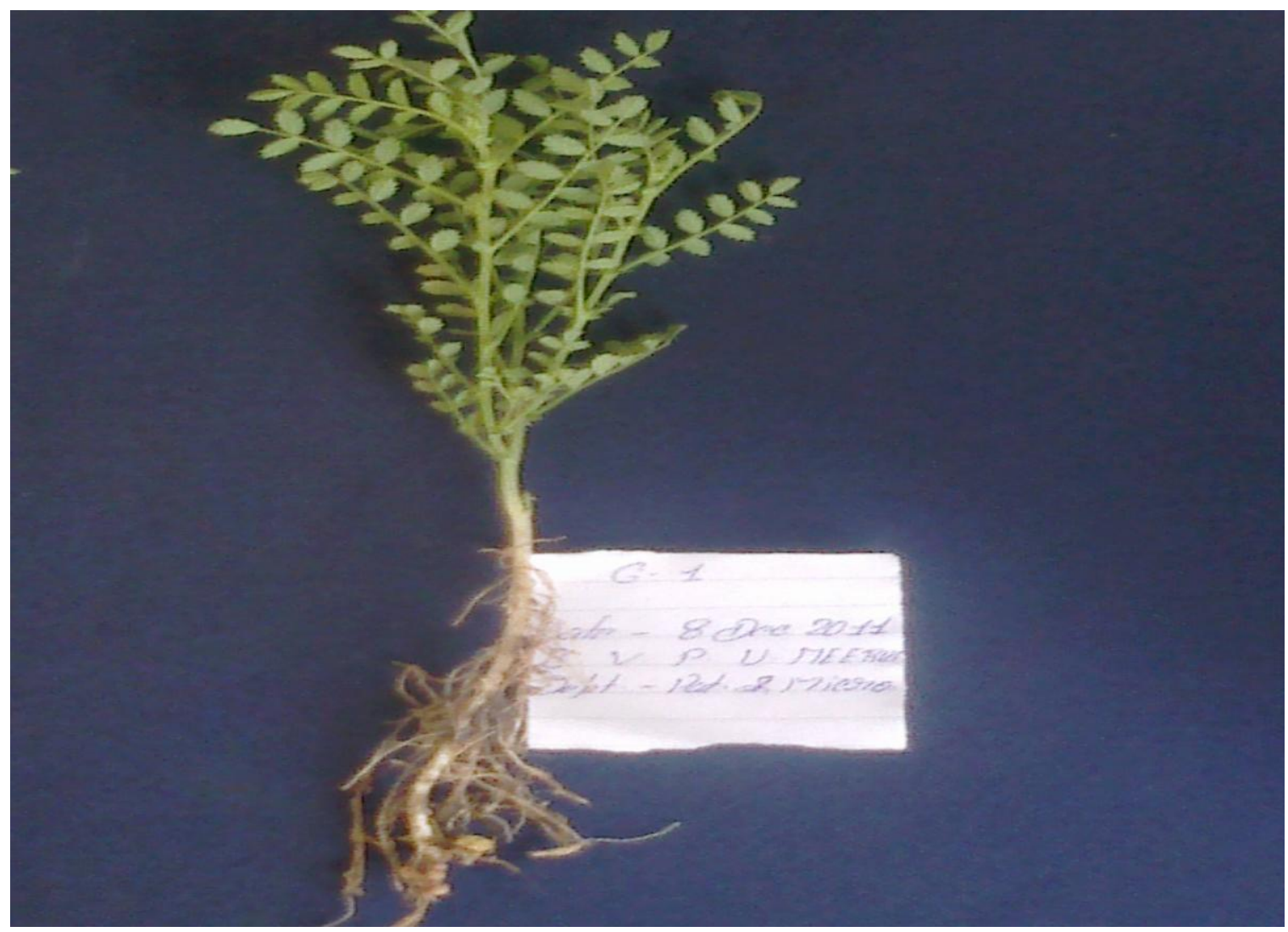


Fig.5 Isolation of a Rhizobium from Urad root nodules on yeast extract mannitol agar

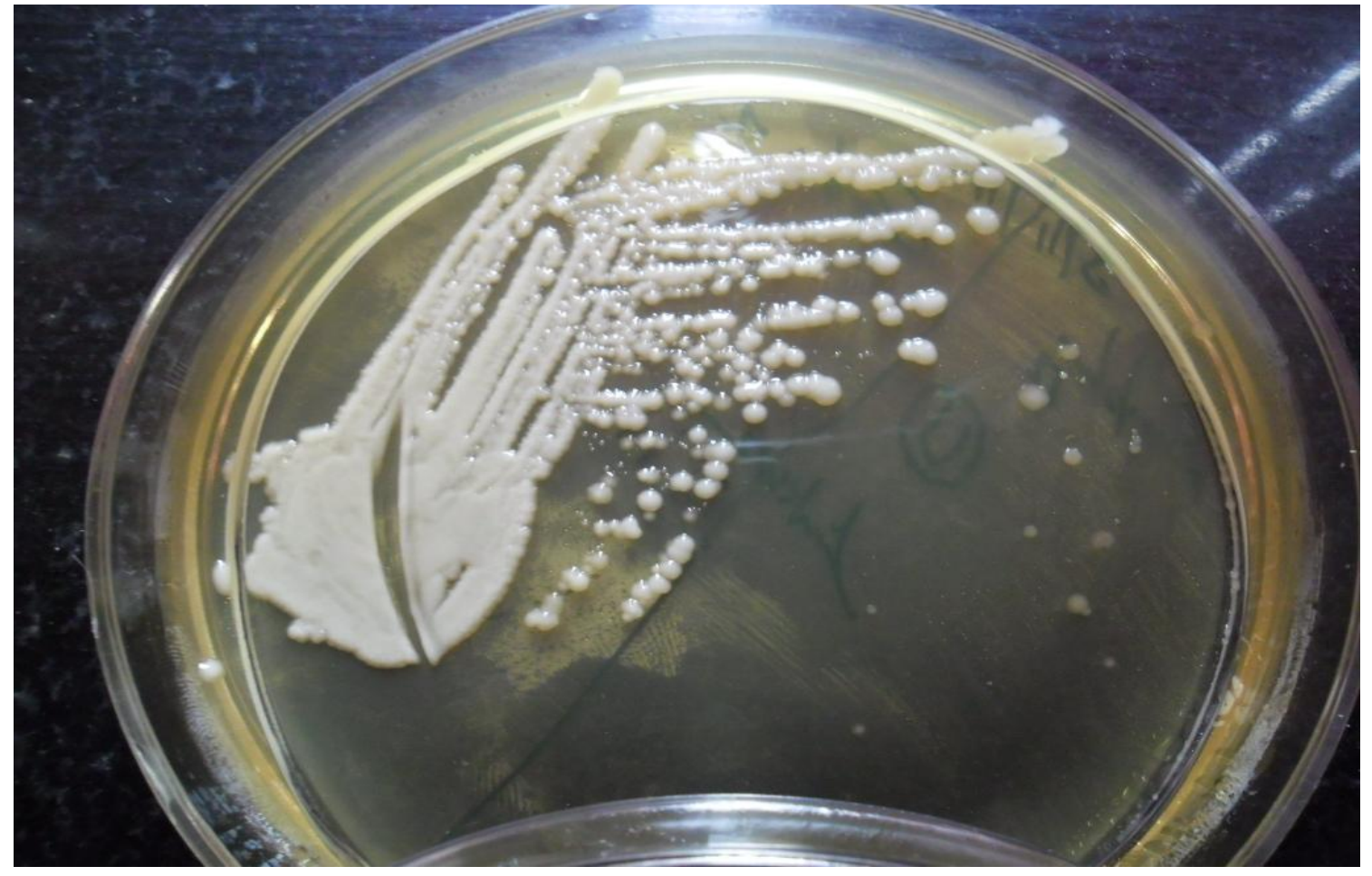

Fig.6 Isolation of a Rhizobium from Chickpea root nodules on yeast extract mannitol agar

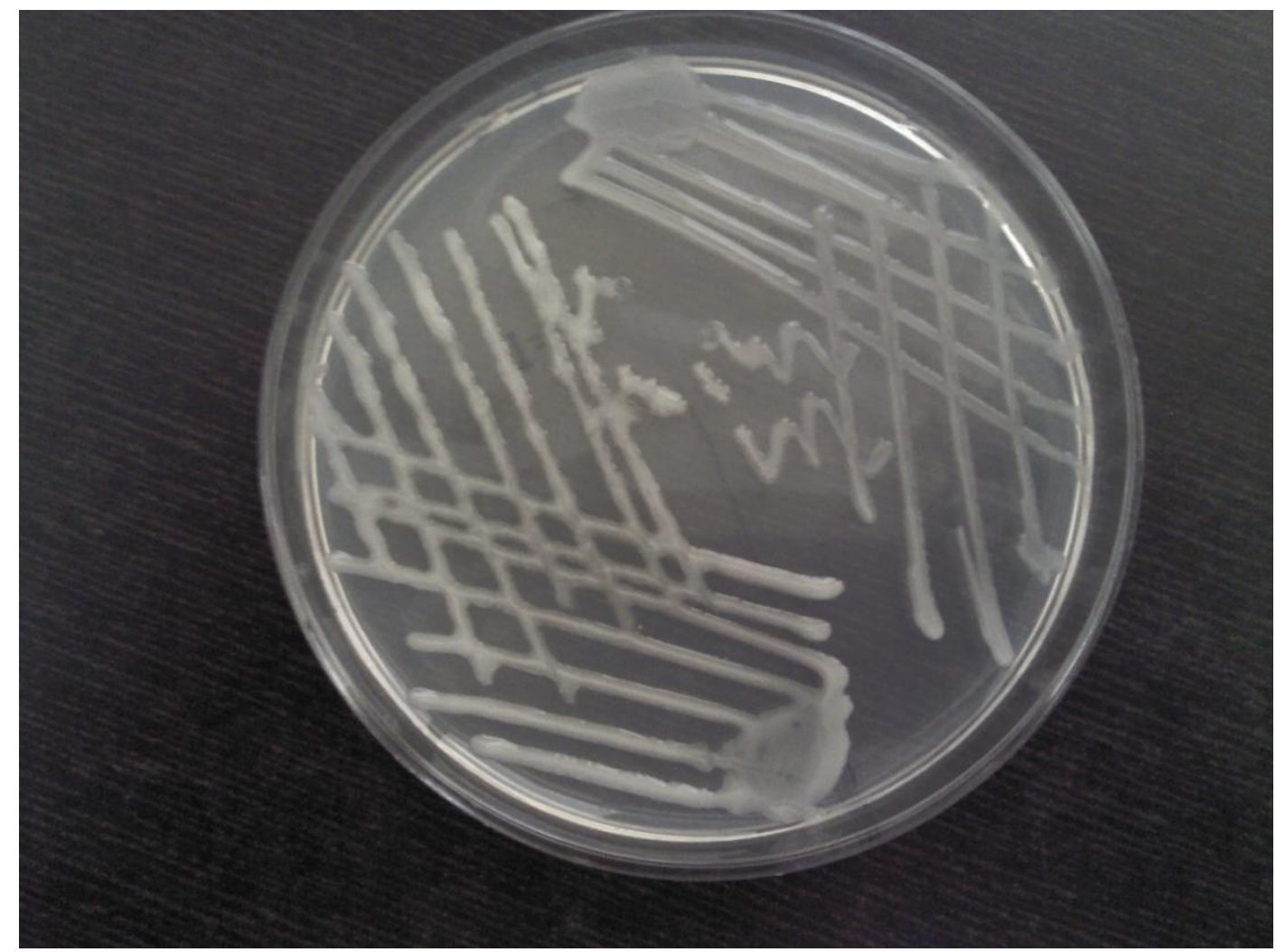


Fig.7 Biochemical reaction of Rhizobium on triple sugar iron agar slants

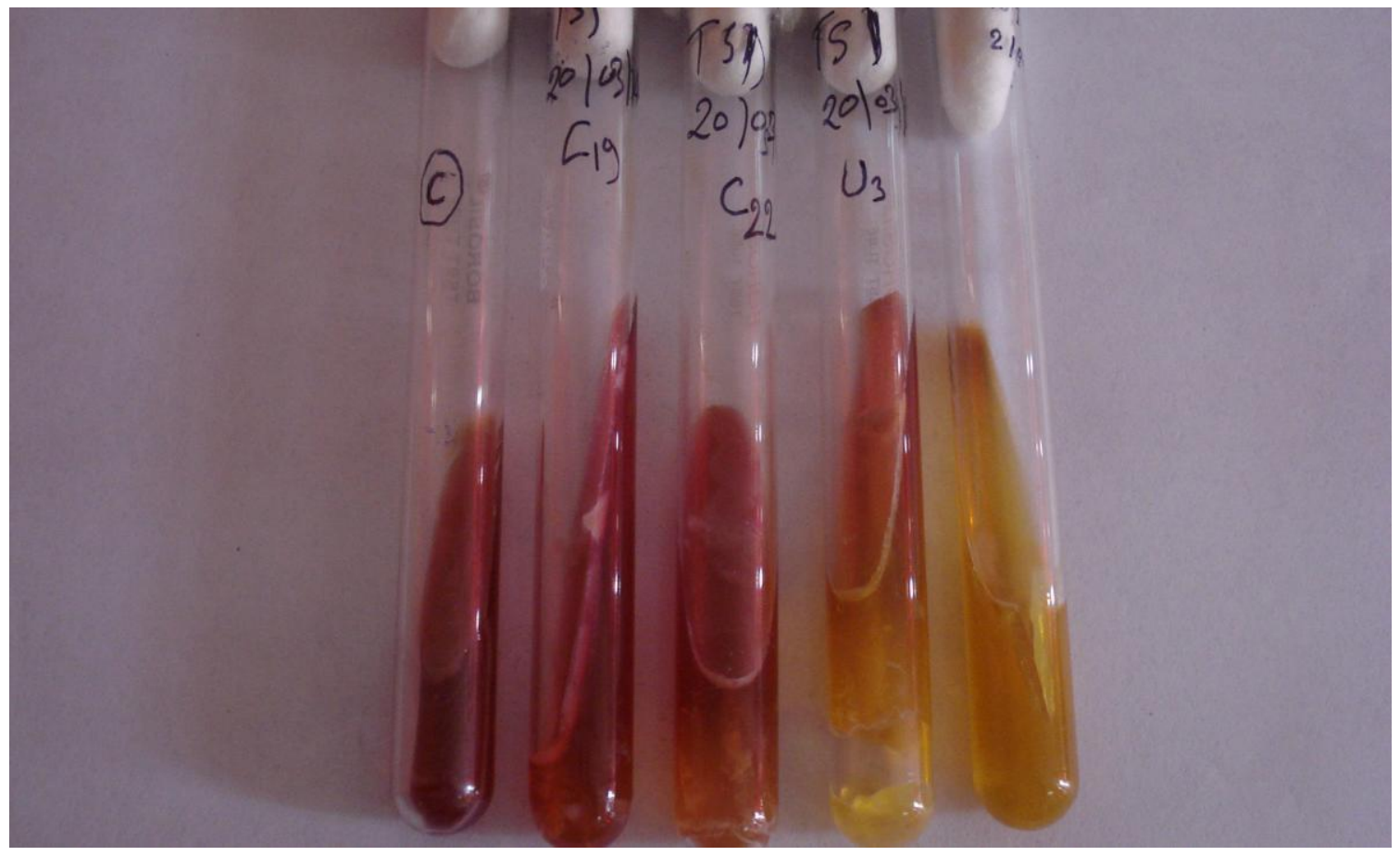

Fig.8 Bubble formation on inoculated yeast extract mannitol agar plate show positive catalase test

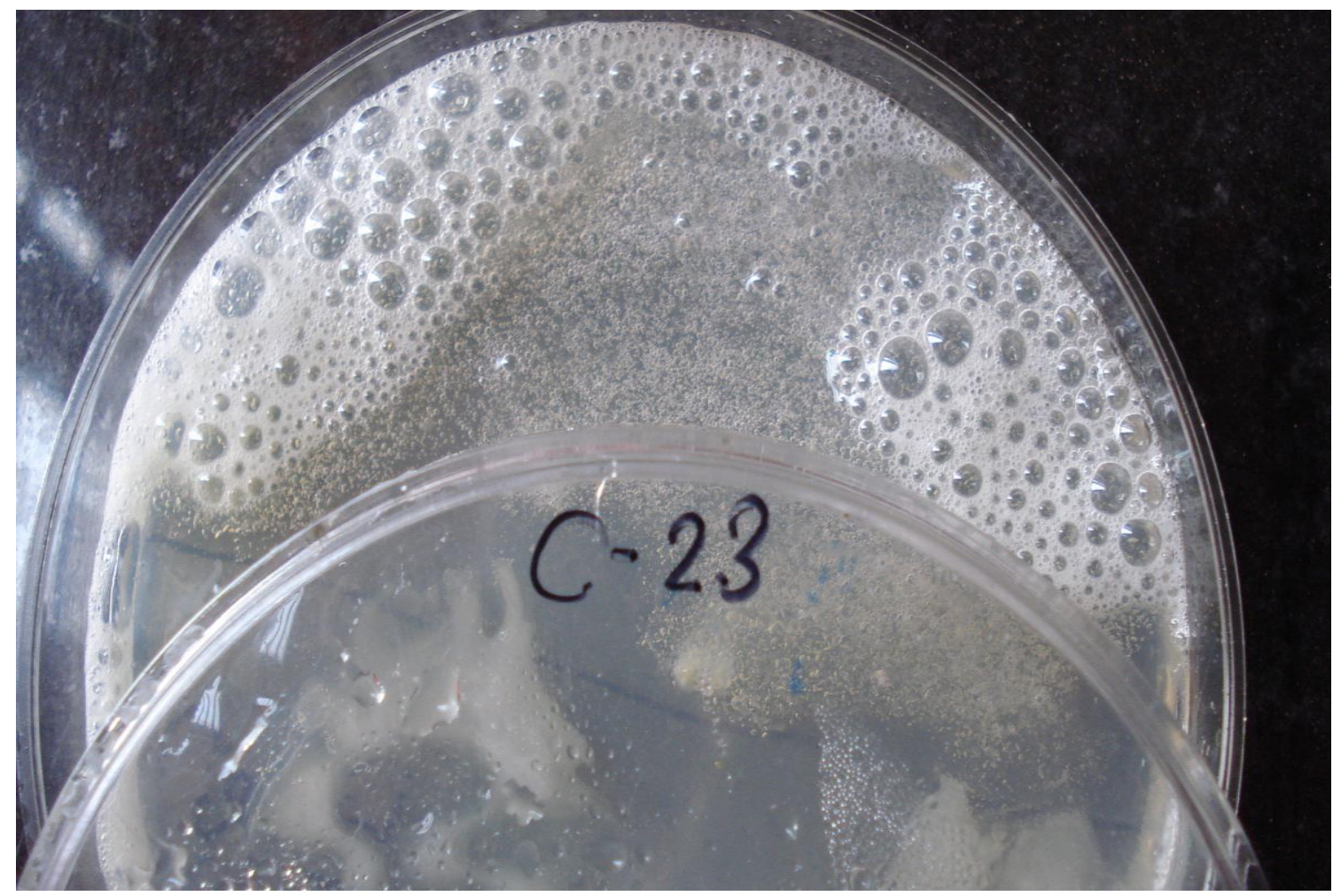




\section{Triple sugar iron test}

All the positive isolates were subjected to the (TSI) test by stab and streak method and were observed for fermentation of the sugar, such as glucose, sucrose and lactose. It was observed that nearly all the isolates except for U1, C3, C13 and C24, fermented the glucose sugar while they lack the ability to ferment both sucrose and lactose. While Glucose peptone agar test was positive with all isolates except for $\mathrm{C} 18$, negative results were found with Gelatin test for all isolates and Catalase test was also found positive for all isolates.

\section{Antibiotic sensitivity test}

Antibiogram tests of all the 21 isolates of Rhizobium (comprising 3 uard samples and 18 chickpea samples) were performed. The results of antibiotic sensitivity are presented in Table 4. All the isolates were found sensitive to Ciprofloxacin (Cf) except $\mathrm{C} 12$ which was partially resistant, Ofloxacin (Of) except C2 which was partially resistant. Norfloxacin (Nx) was susceptible to 11 isolates, resistant to 7 isolates and partial resistant to 3 isolates. Levofloxacin (Le) and Gatifloxacin (Gf) were susceptible to all isolate but Levofloxacin (Le) was partial resistant to $\mathrm{C} 3, \mathrm{C} 8$ and $\mathrm{C} 14$. All the isolates, on the other hand, showed resistance to antibiotics Aztreonam (Ao) and Cotrimoxazole $(\mathrm{Co})$ were showed resistant while Nitrofurantoin (Nf) showed partial resistance to isolates with few exception.

Rhizobium is a Gram negative bacterium which has the capability to fix atmospheric nitrogen. It is particularly important in legumes. In our study, Rhizobium was found in 21 samples out of 37 samples taken from leguminous crops. Samples are surface sterilized with $\mathrm{HgCl}_{2}$ and the plating was done on YEMA medium. As a result, total 21 samples showing mucoid white colonies on
YEMA plates including 3 from urad and 18 from chickpea were subjected to Gram staining and then characterized through biochemical tests. The isolates were identified as of Rhizobium on the basis of different biochemical tests

Our results match with those of De Oliveira et al., (2007), who observed that Rhizobium strains have capability to use starch. Our Rhizobium strains found positive for utilization of glucose as carbon source; similar results were reported by Kucuk et al., (2006). Almost all isolates are incapable of utilizing citrate as carbon source. The Rhizobium strains tested here are found negative for the production of gelatinase enzyme, similar to the findings of Hunter et $a l$. , (2007). Negative gelatinase activity is a feature of Rhizobium. All the isolates were found positive for catalase test indicating the presence of catalase enzyme (Irum Naz, 2009). Most of the isolates were resistant to Aztreonam (Ao) and co-trimoxazole (Co), for other drugs they were mostly sensitive. It might be because of their (isolates) environmental origin, and therefore, sensitive to majority of the drugs.

\section{References}

Aktar M W, Sengupta D and Chowdhury A. 2009. Impact of pesticides use in agriculture: their benefits and hazards. Interdiscip. Toxicol. 2(1): 1-12.

Aneja KR. 2003. Experiments in Microbiology Plant Pathology and Biotechnology. $4^{\text {th }}$ edition, New Age International Publishers, New Delhi, India.

Beneduzi A, Ambrosini A and Passaglia M P L. 2012. Plant growth-promoting rhizobacteria (PGPR): Their potential as antagonists and biocontrol agents. Genetics and Molecular Biology, 35 (4): 1044-1051. 
Chaintreuil C, Giraud E, Prin Y, Lorquin J, Ba A, Gillis M, de Lajudie P, Drefus B. 2000. Photosynthetic Bradyrhizobia are natural endophytes of the African wild rice Oryza breviligulata. Appl. Environ. Microbiol. 66:5437-5447.

Cleyet-Marel, J.C., Di Boniot, R., Beck, D.P. 1990. Chickpea and its root-nodule bacteria implications of their relationships for legume inoculation and biological nitrogen fixation.

De Oliveira, A.N., de Oliveira, L.A., Andrads, Chagas, J.A.F. 2007. Rhizobia amylase production using various starchy substances as carbon substrates. Braz. J. Microbiol. 38: 208-216.

Gupta G, Parihar SS, Ahirwar NK, Snehi SK, Singh V. 2015. Plant Growth Promoting Rhizobacteria (PGPR): Current and Future Prospects for Development of Sustainable Agriculture. J Microb Biochem Technol 7:096-102. doi:10.4172/1948-5948.1000188.

Hajna. 1945. J. Bact.; 49:516.

Hunter, W.J., Kuykendall, L.D., Manter, D.K. 2007. Rhizobium selenireducens spp. nov.: A selenite-Reducing Proteobacteria isolated from a bioreactor. Curr. Microbiol. 55: 455460.

Jordan D C 1982 Transfer of Rhizobium japonicum, Buchanan 1980 to Bradyrhizobium gen. nov., a genus of slow-growing, root nodule bacteria from leguminous plants. Int. J. Syst. Bacteriol. 32, 136-139.

Kligler, I.J. (1918). Modifications of culture media used in the isolation and differentiation of typhoid, dysentery, and allied bacilli. J Exp. Med. 28: 319322.

Kucuk, C., Kivanc, M., and Kinaci, E. 2006. Characterization of Rhizobium spp. Isolated from bean. Turk j. Biol. 30: 127-132.

Lee, J.Y. and Song, S.H. 2007. Evaluation of groundwater quality in coastal areas. implications for sustainable agriculture. Environmental Geology 52: 1231-1242.

MacFaddin. 1990. Biochemical tests for Identification of Medical bacteria, pp: 51-54. Williams and Wilkins, Baltimore, USA.

Mia M. A. B and Shamsuddin Z. H. 2010. Rhizobium as a crop enhancer and biofertilizer for increased cereal production. African Journal of Biotechnology Vol. 9(37): 6001-6009.

Persuna M L. 2014. Characterisation of Rhizobium isolates associated with wild legumes on the basis of antibiotic resistance. Indian J. Sci. Res. 4 (1): 2224.

Rigby, D., Caceres, D. (2001). Organic farming and the sustainability of agricultural systems. Agricultural Systems. 68: 21-40.

Singh, Baljinder, Kaur, Ravneet and Singh, Kashmir. 2008. Characterization of Rhizobiam strain isolated from the roots of Trigonella foenamgraecum (fenugreek). African Journal of Biotechnology Vol. 7 (20), pp. 3671 3676.

\section{How to cite this article:}

Ankur Tyagi, Vijay Kumar, Purushottam and Akash Tomar. 2017. Isolation, Identification, Biochemical and Antibiotic Sensitivity Characterization of Rhizobium Strains from Vigna mungo (L) Hepper, Cicer arietinum L and Vigna radiata (L) R Wilczek in Muzaffarnagar, Uttar Pradesh, India. Int.J.Curr.Microbiol.App.Sci. 6(12): 2024-2035. doi: https://doi.org/10.20546/ijcmas.2017.612.233 